\title{
Excess estrogen sulfoconjugation as the possible cause for a poor sign of parturition in pregnant cows carrying somatic cell clone fetuses
}

\author{
Hiroki Hirayama, Ken Sawai ${ }^{1}$, Satoru Moriyasu, Muneyuki Hirayama ${ }^{2}$, Yuji Goto ${ }^{2}$, \\ Etsushi Kaneko ${ }^{3}$, Akio Miyamoto ${ }^{3}$, Koichi Ushizawa ${ }^{4}$, Toru Takahashi ${ }^{4}$ and Akira Minamihashi ${ }^{5}$ \\ Hokkaido Animal Research Center, Shintoku, Hokkaido 081-0038, Japan, ${ }^{1}$ Department of Animal Science, Faculty of \\ Agriculture, Iwate University, Morioka, Iwate 020-8550, Japan, ${ }^{2}$ National Livestock Breeding Center Tokachi Station, \\ Otofuke, Hokkaido 080-0572, Japan, ${ }^{3}$ Graduate School of Animal and Food Hygiene, Obihiro University of \\ Agriculture and Veterinary Medicine, Obihiro, Hokkaido 080-8555, Japan, ${ }^{4}$ Reproductive Biology Research Unit, \\ Division of Animal Science, National Institute of Agrobiological Sciences, Tsukuba, Ibaraki 305-0901, Japan and \\ ${ }^{5}$ Hokkaido Konsen Agricultural Experiment Station, Nakashibetsu, Hokkaido 086-1135, Japan \\ Correspondence should be addressed to H Hirayama; Email: h.hirayama@agri.pref.hokkaido.jp
}

\begin{abstract}
We conducted this study to elucidate a factor causing a poor sign of parturition and prolonged gestation, which is frequently observed in cows carrying somatic clone fetuses. Pre-partum rises in concentrations of plasma estrone and estradiol-17 $\beta$ in the recipient cows pregnant with clones were subtle. By contrast, the plasma concentration of estrone sulfate in clone pregnancies increased gradually from pre-initiation of parturition induction whereas control cows that received in vivo-derived embryos showed a significant increase at parturition. Therefore, in clone pregnancies, the ratio of estrone/estrone sulfate was low during the pre-partum period compared with control. Messenger RNA expression of estrogen sulfotransferase (SULT1E1) in the placenta at parturition was significantly higher in clone pregnancies than control pregnancies and was localized in binucleate cells (BNC). SULT1E1 mRNA abundance was negatively and positively correlated with concentrations of maternal estrone and estrone sulfate at parturition respectively. Messenger RNA expressions of estrogen sulfatase (STS) and aromatase (CYP19) were similar between clone and control pregnancies and were localized in BNC and caruncular epithelial cells. STS and CYP19 mRNA abundances showed positive correlations with maternal estradiol-17 $\beta$ concentration. The population of BNC in the placenta did not differ between clone and control pregnancies. Plasma cortisol concentration of vaginally delivered newborn clone calves was comparable with those of control, although cesarean section delivered clone calves showed a low concentration. These results suggest that excess estrogen sulfoconjugation is the reason for the perturbed low ratio of active to inactive estrogens and the resulting hormonal imbalance contributes to the lack of overt signs of readiness for parturition in cows pregnant with clones.
\end{abstract}

Reproduction (2008) 136 639-647

\section{Introduction}

The production of viable offspring from nuclear transfer with somatic cells has been reported in a range of domestic species, although the production efficiency is still low (Campbell et al. 2007). Low development rates of clone embryos and a high incidence of gestational losses in early to mid-pregnancy are the most remarkable features in cattle cloning. Additionally, the recipient cows carrying clone fetuses often do not have appreciable relaxation and dilation of the pelvic cavity, cervix, vagina, and external genital at the estimated date of parturition. Pre-partum abnormalities such as prolonged gestation and a lack of readiness for birth in the recipient cows cause dystocia and mortality in perinatal calves, and are factors in decreasing the production efficiency of clone cattle (Heyman et al.
2002). The large offspring syndrome (LOS) that occurs in late gestation is also a characteristic abnormality in cattle cloning (Hill et al. 1999, Chavatte-Palmer et al. 2002, Pace et al. 2002). The syndrome is initiated by nuclear transfer and/or exposure of embryos before the hatched blastocyst stage to unusual environments such as in vitro culture with serum and results in abnormally large calves (Young et al. 1998). However, the recipient cows carrying clone fetuses often lack spontaneous parturition at a normal gestation length, in spite of the maturity of fetal size. A poor sign of parturition associated with LOS requires delivery by cesarean section.

Placental estrogens, estrone $\left(E_{1}\right)$ and estradiol- $17 \beta$ $\left(E_{2}\right)$, have been suggested to play important roles in the parturition process (Wood 1999). Uterine contraction is essential for the process of parturition, and placental 
estrogens influence the activity of the uterine myometrium (Wathes \& Porter 1982). Also, placental estrogens may dilate the cervix that allows passage of the fetus through the birth canal (Breeveld-Dwarkasing et al. 2003). Estrogens are synthesized by aromatase (CYP19), which converts androgens into estrogens in fetal cotyledonary tissue (Schuler et al. 2006), and show a dramatic increase in maternal plasma during the prepartum period (Takenouchi et al. 2004). The activity of estrogen is regulated by sulfoconjugation that inhibits the binding of steroids to their nuclear receptors. Estrone sulfate $\left(E_{1} S\right)$ is an inactive form catalyzed by estrogen sulfotransferase (SULT1E1), the activity of which is detected mainly in fetal cotyledonary tissue (Hoffmann et al. 2001). Conversely, sulfoconjugated estrogens may also be precursors of the production of free estrogens, depending on placental estrogen sulfatase (STS) activity (Rossier \& Pierrepoint 1974).

Cortisol, a well-known trigger initiating the parturition process, induces an increase in the synthesis of estrogens in the placenta (Wood 1999). A previous report suggested that the prenatal cortisol rise in clone fetuses was insufficient and therefore parturition was not spontaneous (Matsuzaki \& Shiga 2002). By contrast, another study demonstrated a normal cortisol response to adrenocorticotropic hormone (ACTH) in neonatal clone calves, implying that the calves had a mature cortisol secretion system (Chavatte-Palmer et al. 2002).

Previously, several investigators suggested morphological and functional abnormalities of the placenta in clone fetuses in various gestational stages (Hill et al. 2001, Hashizume et al. 2002, Constant et al. 2006); however, the role of the placenta in the final process of pregnancy, namely placental steroidgenesis and regulation of hormonal activity, is not fully understood. Therefore, analyses of placental events on the parturition process may help to overcome problems in the pre-partum period. The aim of this study was to elucidate the factors causing a poor sign of parturition and prolonged gestation in clone pregnancies. We assessed maternal plasma $E_{1}, E_{2}, E_{1} S$, and progesterone $\left(\mathrm{P}_{4}\right)$ concentrations during the pre-partum period and plasma cortisol concentration in newborn calves. Furthermore, we analyzed mRNA expression levels and localization of estrogen-metabolizing genes, SULT1E1, STS, and CYP19, in the placenta at parturition.

\section{Results \\ Calves}

Birth weights were measured in 19 vaginally delivered clone calves (VC), 15 cesarean section delivered clone calves (CC), and 9 vaginally delivered calves which were produced by embryo transfer of in vivo-fertilized embryos (Control). Mean birth weights of VC (43.3 \pm $2.1 \mathrm{~kg} ; P<0.05)$ and CC $(55.9 \pm 3.9 \mathrm{~kg} ; P<0.01)$ were significantly heavier than that of Control $(29.0 \pm 1.6 \mathrm{~kg})$.
Birth weights ranged from 20 to $60 \mathrm{~kg}$, 20 to $75 \mathrm{~kg}$, and 25 to $35 \mathrm{~kg}$ for VC, CC, and Control respectively.

\section{Maternal plasma hormone concentrations}

Hormone concentrations were measured in 13,8 , and 4 cows for VC, CC, and Control respectively. The data are shown in Fig. 1.

Plasma $\mathrm{E}_{1}$ concentration in Control recipients increased progressively from day 271 of pregnancy to term, and a remarkable rise had already occurred before the induction of parturition. CC recipients had significantly lower plasma $E_{1}$ concentration in the preparturition period compared with Control recipients. In the same period, plasma $E_{1}$ concentration of $V C$ recipients tended to be lower than Control recipients, but this was not significantly different.

Control recipients exhibited a marked increase in plasma $E_{2}$ concentration prior to the induction of parturition. Plasma $E_{2}$ concentration of $V C$ recipients increased gradually, but clone pregnancies showed lower concentrations than Control recipients in the pre-parturition period.

Plasma $E_{1} S$ concentration in clone pregnancies increased gradually from pre-initiation of the induction of parturition whereas plasma $\mathrm{E}_{1} \mathrm{~S}$ concentration in Control recipients only increased at term. As a result, plasma $\mathrm{E}_{1} \mathrm{~S}$ concentration in clone pregnancies tended to be higher than those in Control recipients during the preparturition period.

$\mathrm{E}_{1} / \mathrm{E}_{1} \mathrm{~S}$ ratio in Control recipients showed progressive increase from day 271 of pregnancy to just before prostaglandin $(\mathrm{PG}) \mathrm{F}_{2 \alpha}$ treatment and then declined at term. Increase in the $E_{1} / E_{1} S$ ratio in $V C$ recipients was modest in comparison and CC recipients did not show any increase in the ratio throughout the same period.

Plasma $\mathrm{P}_{4}$ concentration decreased gradually from initiation of the induction of parturition and there was no significant difference in VC, CC, and Control recipients at any time point.

\section{Plasma cortisol concentrations in calves}

Plasma cortisol concentrations in calves were measured in $17 \mathrm{VC}, 10 \mathrm{CC}$, and 9 Control. Plasma cortisol concentrations in VC $(104.4 \pm 23.1 \mathrm{ng} / \mathrm{ml})$ and Control $(93.4 \pm 15.0 \mathrm{ng} / \mathrm{ml})$ were similar and tended to be higher than for CC $(60.1 \pm 19.1 \mathrm{ng} / \mathrm{ml} ; P>0.05)$.

\section{Messenger RNA abundances of SULT1E1, STS, and CYP19 in placentomes at parturition}

Messenger RNA abundances were analyzed in 7, 10 , and 4 samples in the cotyledonary villi (COT) and 5,9 , and 4 samples in the caruncle areas (CAR) for $\mathrm{VC}$, $\mathrm{CC}$, and Control respectively. 
Messenger RNA abundance for SULT1E1 did not differ significantly between COT and CAR (Fig. 2A). Placental mRNA abundances of SULT1E1 were significantly higher in VC and CC than in Control.
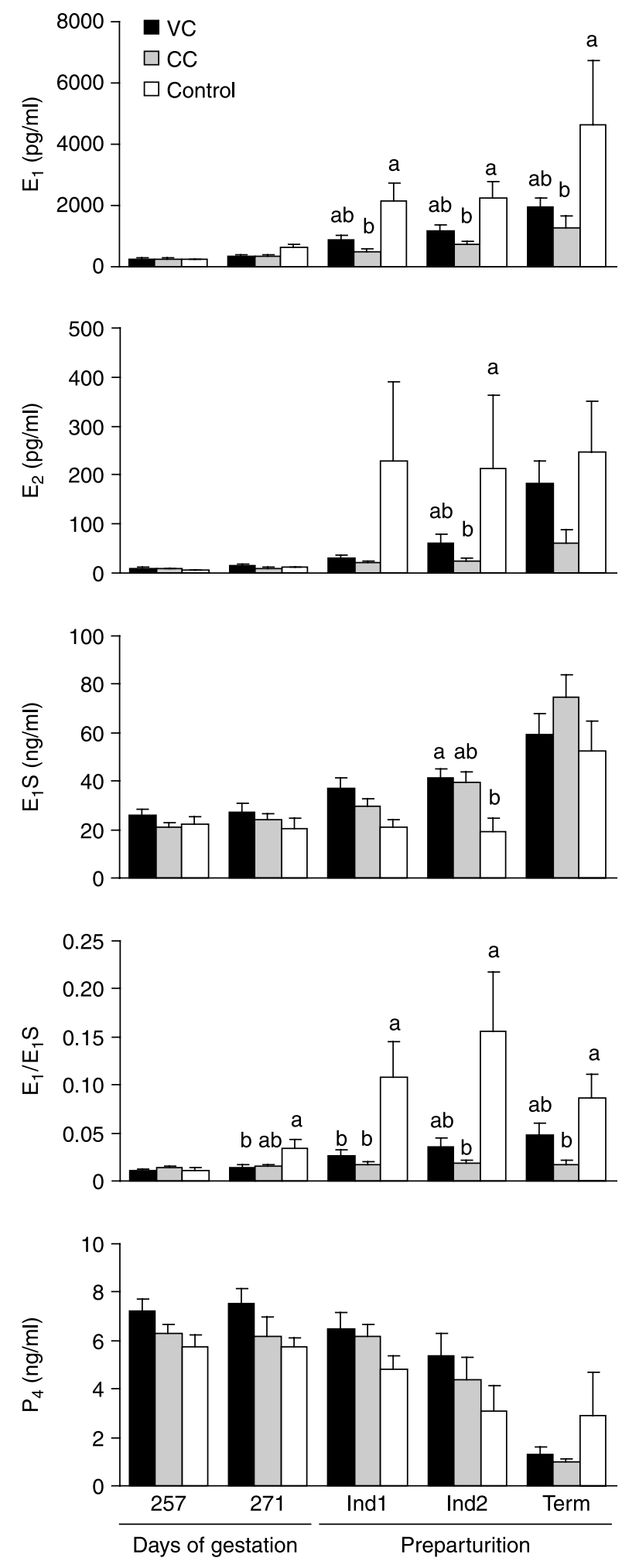

Messenger RNA abundance for STS was significantly higher in CAR than in COT (Fig. 2B). There was no difference between $\mathrm{VC}, \mathrm{CC}$, and Control placentomes.

Messenger RNA abundance for CYP19 was significantly higher in COT than in CAR (Fig. 2C). There was no difference between $\mathrm{VC}, \mathrm{CC}$, and Control placentomes.

\section{Correlations between placental mRNA abundances and estrogen concentrations in clone pregnancies}

As shown in Table 1, mRNA abundance of SULT1E1 in COT was negatively correlated with maternal plasma $E_{1}$ concentration $(P<0.05)$ and positively correlated with maternal plasma $\mathrm{E}_{1} \mathrm{~S}$ concentration $(P<0.05)$. Positive correlations between mRNA abundances of STS and CYP19 in CAR and maternal plasma $\mathrm{E}_{2}$ concentration were also statistically significant.

\section{In situ hybridization of SULT1E1 and STS and immunohistochemical staining of CYP19}

By in situ hybridization, positive signals for SULT1E1 transcripts were detected in binucleate cells (BNC) in both clone and control pregnancies (Fig. 3). Positive signals for STS were detected in BNC and caruncular epithelial cells in both clone and control pregnancies (Fig. 3).

By immunohistochemistry, CYP19 was localized to BNC and caruncular epithelial cells in both clone and control pregnancies (Fig. 4).

\section{$B N C$ in placenta}

BNC in placental sections was counted in 9, 10, and 4 samples of VC, CC, and Control respectively.

There were no significant differences among the numbers of $\mathrm{BNC}$ in VC $\left(18.8 \pm 1.4 / 0.1 \mathrm{~mm}^{2}\right)$, CC $\left(18.6 \pm 1.7 / 0.1 \mathrm{~mm}^{2}\right)$, and Control $\left(18.9 \pm 1.8 / 0.1 \mathrm{~mm}^{2}\right)$.

\section{Discussion}

We evaluated hormonal status relating to parturition and placental expression of estrogen-metabolizing genes. In clone pregnancies, the ratio of active/inactive forms of maternal estrogens was low during the pre-partum period and mRNA expression of SULT1E1, which contributes to

Figure 1 Maternal plasma hormone concentrations and $E_{1} / E_{1} S$ ratio from late pregnancy to term. Dexamethasone was administered at days 276-288 of pregnancy, and $\mathrm{PGF}_{2 \alpha}$ and estriol were administered $24 \mathrm{~h}$ later. Calves were delivered within 2 days after administration of $\mathrm{PGF}_{2 \alpha}$. Ind1, immediately before administration of dexamethasone; Ind 2, immediately before administration of $\mathrm{PGF}_{2 \alpha}$ and estriol. Different letters for each group present statistical difference $(P<0.05)$ at each time point. VC, vaginally delivered clone calves; $C C$, cesarean section delivered clone calves; Control, vaginally delivered calves that were produced by embryo transfer of in vivo-fertilized embryos. 

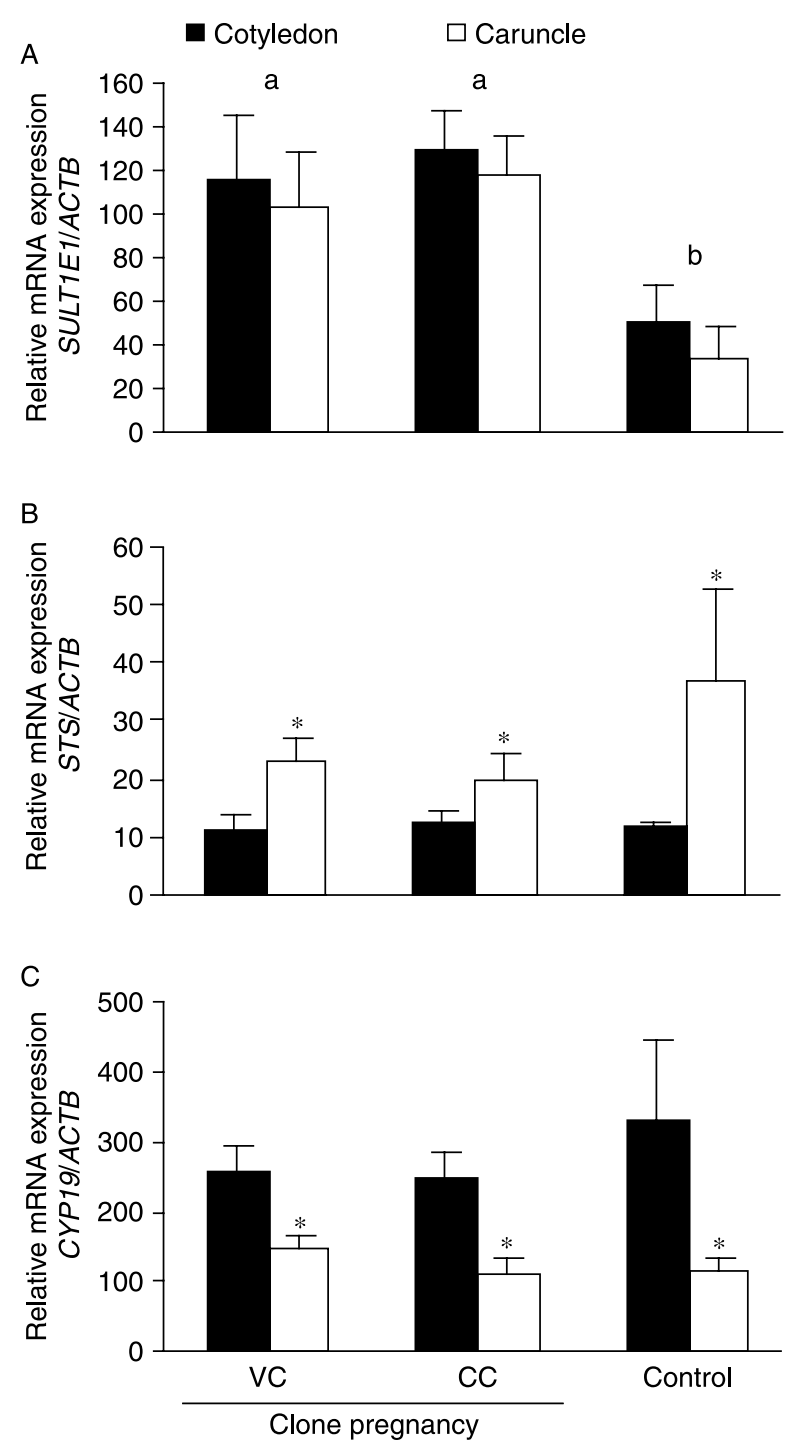

Figure 2 mRNA expression levels of (A) SULT1E1, (B) STS, and (C) CYP19 in cotyledonary and caruncular tissues at parturition. Statistical analysis was performed using two-way ANOVA and Scheffe's test. In all genes analyzed, there was no interaction between groups and tissues. Different letters for each group present statistical difference $(P<0.05)$. *Expression levels between cotyledon and caruncle were significantly different for STS $(P<0.01)$ and CYP19 $(P<0.01)$ and but for SULT1E1. VC, vaginally delivered clone calves; $C C$, cesarean section delivered clone calves; Control, vaginally delivered calves that were produced by embryo transfer of in vivo-fertilized embryos.

the inactivation of estrogens by sulfoconjugation, was upregulated. This suggests that the disruption of the regulation of estrogen activity in the placenta is correlated with abnormalities of the parturition process in clone pregnancies.

The rise of plasma $E_{1}$ and $E_{2}$ concentrations in cows carrying control fetuses started before the induction of parturition. By contrast, plasma estrogen concentration in cows carrying clone fetuses was low at that time, and the increase during the last few days of pregnancy was also subtle. Cows that delivered calves via cesarean section showed particularly low levels of plasma estrogens. Therefore, our results suggested that the estrogen activity necessary for the parturition process was insufficient in clone pregnancies, in spite of an adequate gestation length and the induction of parturition. In addition, plasma $\mathrm{E}_{1} \mathrm{~S}$ concentration in clone pregnancies tended to be higher during that period. Maternal $\mathrm{E}_{1} \mathrm{~S}$ concentration is usually 10- to 15 -fold higher than that of $E_{1}$ during most of the gestation period; however, in cows carrying clone fetuses, plasma $\mathrm{E}_{1} \mathrm{~S}$ concentrations were $\sim 20$ - to 60 -fold higher than those of $E_{1}$ at parturition, so the $E_{1} / E_{1} S$ ratio was very low during late gestation. Therefore, the apparent lack of preparation for parturition in cows carrying clone fetuses could be explained by insufficient estrogen synthesis and/or increased metabolism of active estrogens to inactive estrogens.

Clone pregnancies exhibited high placental SULT1E1 expression compared with control pregnancies, and it seemed that sulfoconjugation activity in clone placenta was facilitated at parturition. Indeed, SULT1E1 mRNA abundance in COT of clone pregnancies correlated negatively and positively with maternal plasma $E_{1}$ and $\mathrm{E}_{1} \mathrm{~S}$ concentrations respectively. Although we have not obtained a dataset of mRNA abundance associated with plasma estrogen concentration in control pregnancies, the present results suggested that abundantly expressed SULT1E1 might inhibit the pre-partum rise of unconjugated estrogens. Previous studies clearly showed that SULT1E1 located in BNC by immunohistochemistry (Brown et al. 1987) and COT had high sulfoconjugation activity compared with CAR (Hoffmann et al. 2001). In this study, because in situ hybridization signals to SULT1E1 were localized in BNC, RT-PCR amplicons detected in CAR might be due to contamination from COT when tissues were separated manually.

The placental BNC population in clone pregnancies during early to mid-gestation (days 30-150) has been analyzed by several investigators, with results ranging from fewer (Hashizume et al. 2002, Arnold et al. 2006) or similar (Hoffert et al. 2005) to more (Ravelich et al. 2004) compared with pregnancies with in vivo- and in vitro-derived embryos. The present study showed that the $\mathrm{BNC}$ population at full term was similar in clone and control pregnancies, so it can be surmised that increased SULT1E1 mRNA abundance in clone placenta was due to increased transcription of the gene and/or increased proportion of SULT1E1 producing BNC.

Although $\mathrm{P}_{4}$ and androgen appear to induce the transcription of SULT1E1 in human endometrium and Leydig cells respectively (Falany \& Falany 1996, Qian \& Song 1999), the transcriptional control of SULT1E1 in BNC is still unclear. On the other hand, it is known that the concentration of maternal sulfoconjugated estrogen, $E_{1} S$, positively correlates with the birth weight of calves and the weight of COT (Echternkamp 1993, Zhang et al. 1999). In addition, $E_{1}, E_{2}$, and $E_{1} S$ concentrations in twinbearing cows are significantly higher than those in 
Table 1 Correlation coefficient between estrogen concentrations in maternal plasma and gene expression levels in placental tissues in clone pregnancy.

\begin{tabular}{|c|c|c|c|c|c|c|c|}
\hline \multirow[b]{2}{*}{ Estrogen } & \multirow[b]{2}{*}{$\begin{array}{c}\text { Maternal plasma } \\
\text { concentration }\end{array}$} & \multicolumn{2}{|c|}{ SULT1E1 mRNA } & \multicolumn{2}{|c|}{ STS mRNA } & \multicolumn{2}{|c|}{ CYP19 mRNA } \\
\hline & & COT & CAR & COT & CAR & COT & CAR \\
\hline $\mathrm{E}_{1}$ & $1169 \pm 262(\mathrm{pg} / \mathrm{ml})$ & $-0.71 *$ & -0.48 & 0.56 & 0.32 & 0.45 & 0.60 \\
\hline$E_{1} S$ & $61.1 \pm 10.3(\mathrm{ng} / \mathrm{ml})$ & $0.79 *$ & 0.25 & -0.23 & -0.07 & 0.05 & -0.13 \\
\hline$E_{2}$ & $93.3 \pm 32.1(\mathrm{pg} / \mathrm{ml})$ & -0.65 & -0.39 & 0.62 & $0.69 *$ & 0.50 & $0.84^{+}$ \\
\hline
\end{tabular}

${ }^{*} P<0.05,{ }^{\dagger} P<0.01$. Two vaginally delivered and seven cesarean section delivered clone calves were analyzed.

singleton cows during the third trimester (Takahashi et al. 1997, Patel et al. 1999). In these cases, sulfoconjugation may be facilitated in association with the increase in placental estrogen synthesis. Morphological and histological studies have shown enlarged placentomes and overgrowth of COT in clone pregnancies (Lee et al. 2004, Constant et al. 2006), and the birth weight of clone calves in this study was significantly heavier. Also in this study, there was a positive correlation between $\mathrm{E}_{1} \mathrm{~S}$ concentration and birth weight in the pooled dataset comprising VC, CC, and Control pregnancies $(r=0.43, P=0.032)$. However, while clone pregnancies had elevated maternal $E_{1} S$ concentration, $E_{1}$ and $E_{2}$ were actually decreased relative to Control pregnancies. Therefore, it appears that in clone pregnancies placental sulfoconjugation by SULT1E1 is not adequately regulated.

Placental expression levels of STS and CYP19 mRNA did not differ between clone and control pregnancies. At the time of parturition of clone fetuses, mRNA abundances of these genes in placentomes were positively correlated with maternal $\mathrm{E}_{2}$ concentrations. Therefore, it appears that STS and CYP19 contribute to the progress of parturition by desulfation and de novo synthesis of estrogen respectively. Data by real-time RT-PCR showing high STS expression in CAR and high CYP19 expression in COT agreed with the previous reports on normal pregnancies (Tsumagari et al. 1993, Hoffmann et al. 2001). Also, the localization of positive cells for STS and CYP19 is consistent with earlier reports (Schuler et al. 2006, Greven et al. 2007). These results suggest that excess sulfoconjugation of estrogens is a possible cause for a poor sign of parturition and prolonged gestation in clone pregnancies, rather than insufficient supply of active estrogens.

The induction of parturition in pregnant cows using dexamethasone and $\mathrm{PGF}_{2 \alpha}$ has been performed in many studies on somatic clone cattle (Hill et al. 1999, 2001, Matsuzaki \& Shiga 2002, Pace et al. 2002). This is mainly conducted to avoid dystocia due to LOS and prolonged gestation. Dexamethasone is a synthetic glucocorticoid and acts as cortisol, which is secreted from the fetal adrenal cortex. It is known that cortisol enhances estrogen synthesis in the placenta and plays a major role in the initiation of parturition (Wood 1999). Matsuzaki \& Shiga (2002) reported that the plasma concentration of cortisol in neonatal clone calves was significantly lower than that in control calves, which were produced by artificial insemination and in vitro fertilization. By contrast, we found similar cortisol concentrations between vaginally delivered clone and control calves. Although the reason for the contradictory results between the two studies is unknown, the present study suggested that clone calves had the ability to synthesize cortisol at parturition. In support of this notion, the results of an ACTH stimulation test showed that the adrenocortical response of neonatal clone calves was normal (Chavatte-Palmer et al. 2002). In this study, cesarean section delivered clone calves, which should not be stressed in the birth canal, had slightly lower
SULT1E1
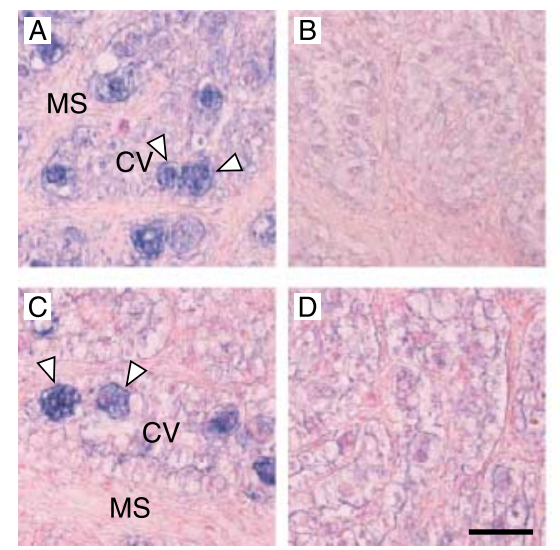

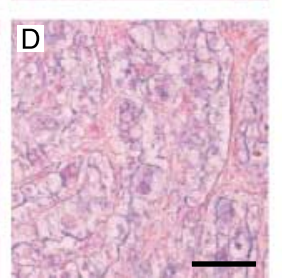

STS

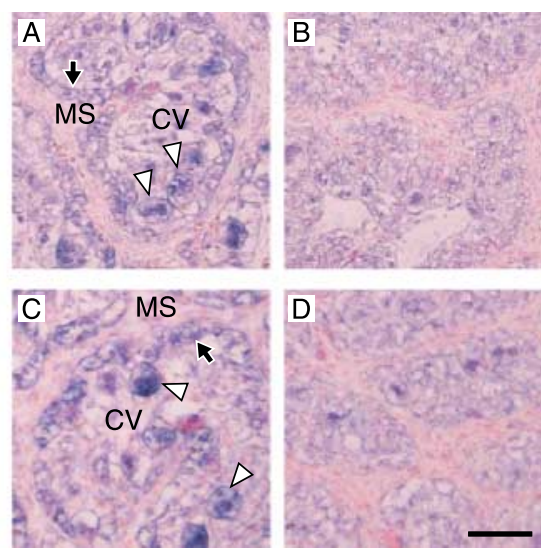

Figure 3 Localization of SULT1E1 and STS mRNA in bovine placentome at parturition. SULT1E1 mRNA was detected in binucleate cells (arrowheads) by in situ hybridization. STS mRNA was detected in binucleate cells (arrowheads) and caruncular epithelial cells (arrow) by in situ hybridization. Placentome of clone calves was hybridized with DIG-labeled (A) antisense cRNA probe and (B) sense cRNA probe. Placentome of control calves was hybridized with DIG-labeled (C) anti-sense cRNA probe and (D) sense cRNA probe. CV, chorionic villus; MS, maternal septum. Scale bar $=50 \mu \mathrm{m}$. 

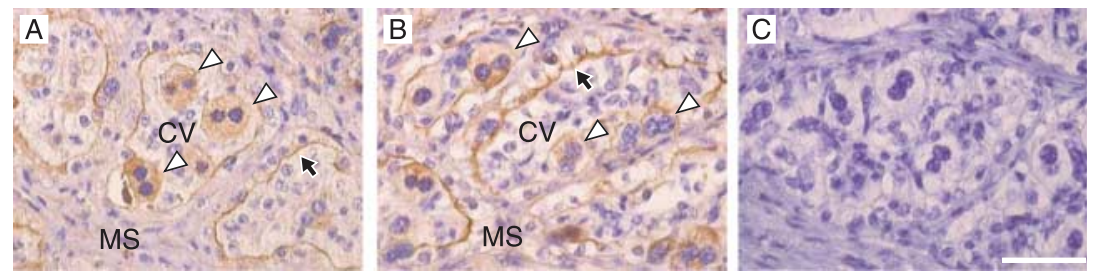

Figure 4 Localization of aromatase (CYP19) in bovine placentome at parturition. CYP19 was detected in binucleate cells (arrowheads) and caruncular epithelial cells (arrow) by immunohistochemistry. Placentome of (A) clone calves and (B) control calves was incubated with antiaromatase polyclonal antibody. (C) Negative control was incubated without anti-aromatase polyclonal antibody. CV, chorionic villus; MS, maternal septum. Scale bar $=50 \mu \mathrm{m}$.

cortisol concentration. For these calves, there is also a possibility that preparation for parturition was poorer, resulting in having to be delivered by cesarean section and this may be reflected in the lower cortisol concentration in the calves. Furthermore, since $\mathrm{P}_{4}$ concentration decreased similarly following $\mathrm{PGF}_{2 \alpha}$ treatment in cows carrying clone and control fetuses, luteolysis progressed normally regardless of the origin of the fetus. Thus, we could not find any abnormality of the neonatal cortisol level and luteolysis, which contribute toward fetal maturation and signal readiness for birth. However, to our knowledge, there has been no report demonstrating the normality of cortisol synthesis in prenatal clone fetuses. Further study to confirm the secretion level of cortisol in clone fetuses is necessary.

In summary, this report revealed that maternal estrogen concentrations in clone pregnancies did not increase sufficiently in the pre-partum period. Due to elevated placental SULT1E1 expression level, it is suggested that excess placental sulfoconjugation is a factor inhibiting the pre-partum rise of active estrogen and causes a poor sign of parturition in clone pregnancies.

\section{Materials and Methods \\ Animals and sample collection}

Clone calves were produced by nuclear transfer using fibroblast cells derived from the skin of Japanese black male calves as donor nuclei. Procedures for the production of control calves were described previously (Sawai et al. 2005). Control calves (Japanese black) were produced by transfer of in vivo-fertilized embryos into recipient cows. Calves were born at the Hokkaido Animal Research Center and the National Livestock Breeding Center Tokachi Station. The production of clone cattle was approved by the Animal Experiment Committee.

The induction of parturition in cows was achieved with $20 \mathrm{mg}$ i.m. dexamethasone (Denka Pharmaceutical Co., Kawasaki, Japan) at days 276-288 of pregnancy, followed by $\mathrm{PGF}_{2 \alpha}(0.75-$ $1 \mathrm{mg}$ i.m. cloprostenol (Resipron-C, Aska Pharmaceutical Co., Ltd, Tokyo, Japan) or $25 \mathrm{mg}$ i.m. tromethamine dinoprost (Pronalgon-F injection, Pharmacia)) and $20 \mathrm{mg}$ i.m. estriol (Holin, Teikoku Zoki Co., Tokyo, Japan) 24 h later. The calves were delivered 2 or 3 days after the administration of dexamethasone. Some control calves were delivered by cesarean section, after the induction of parturition. The decision whether to allow vaginal delivery or to perform cesarean section was based on subjective comparison of fetal size, maternal pelvic diameter, and soft birth canal diameter. Average days of gestation when induction of parturition was initiated were day 282 (range days 277-288), day 283 (days 276-285), and day 283 (days 280-288) for VC, CC, and Control respectively.

Venous blood samples of cows were taken at days 257 and 271 of pregnancy and just before dexamethasone treatment, $\mathrm{PGF}_{2 \alpha}$ treatment, and parturition. Venous blood samples of calves were taken just after parturition. Plasma was harvested by centrifugation and stored at $-20^{\circ} \mathrm{C}$ until analyses.

Placentomal tissues were collected manually, immediately after vaginal delivery and cesarean section, through either the birth canal or incision site of the uterus respectively. Placentomes were fixed in $10 \%$ formalin neutral buffer solution $(\mathrm{pH} 7.4)$ and then embedded in paraffin wax and stored at $4{ }^{\circ} \mathrm{C}$ prior to in situ hybridization and immunohistochemistry. Additional placentomes were separated into two portions manually, COT and CAR, and the collected samples were stored at $-80^{\circ} \mathrm{C}$ prior to RNA extraction.

The number of animals and samples used for each assay is given in the Results.

\section{Hormone assays}

Hormone assays were carried out in duplicate by doubleantibody enzyme immunoassay (EIA), as described previously (Miyamoto et al. 1992).

$E_{1}$ concentration was measured by the EIA technique, as described by Acosta et al. (2002). Dilutions of anti-estrone-3glucuronide-BSA IgG (anti- $\mathrm{E}_{1}$; Cosmo Bio Co., Ltd, Tokyo, Japan) and estrone-3-carboxymethyl ether-horseradish peroxidase (CME-HRP) (Cosmo Bio) were 150000 and 70000 respectively. Cross-reactivity of anti- $\mathrm{E}_{1}$ with $\mathrm{E}_{1}, \mathrm{E}_{1}$-glucuronide, $E_{1} S$, and $E_{2}$ were $100,17,25$, and $1 \%$ respectively. The standard curve for $E_{1}$ ranged from 0.75 to $1000 \mathrm{pg} / \mathrm{ml}$. The ED50 value of the assay was $423 \mathrm{pg} / \mathrm{ml}$. The averages of intraand inter-assay coefficients of variation $(\mathrm{CVs})$ were 8.0 and $12.2 \%$ respectively.

Plasma $\mathrm{E}_{2}, \mathrm{P}_{4}$, and cortisol were determined after extraction by diethyl ether. The EIA for $E_{2}, P_{4}$, and cortisol was performed as described previously (Acosta et al. 1998, 2002). The standard curve ranged from 2 to $2000 \mathrm{pg} / \mathrm{ml}$ for $\mathrm{E}_{2}, 0.05$ to $50 \mathrm{ng} / \mathrm{ml}$ for $\mathrm{P}_{4}$, and 0.1 to $100 \mathrm{ng} / \mathrm{ml}$ for cortisol. ED50 values of the assay for $\mathrm{E}_{2}, \mathrm{P}_{4}$, and cortisol were $40 \mathrm{pg} / \mathrm{ml}, 1.8 \mathrm{ng} / \mathrm{ml}$, and $6.4 \mathrm{ng} / \mathrm{ml}$ respectively. The average of inter- and intra-assay 
CVs for $\mathrm{E}_{2}, \mathrm{P}_{4}$, and cortisol were 7.1 and $9.8 \%, 6.2$ and $9.3 \%$, and 8.9 and $11.1 \%$ respectively.

$\mathrm{E}_{1} \mathrm{~S}$ concentration was measured by the EIA technique described by Isobe \& Nakao (2002) with minor modifications. Anti-estrone-3-sulfate-6-(O-carboxymethyl) oxime (CMO)-BSA IgG (anti- $E_{1} S$ ) and estrone-3-sulfate-6-CMO-HRP ( $\left.E_{1} S-H R P\right)$ were generously supplied by Kambegawa Institute (Tokyo, Japan). Cross-reactivities of anti- $E_{1} S$ with $E_{1} S, E_{1}$, estrone-3glucuronide, estradiol-3-sulfate, and estradiol-3-glucuronide were $100,8,4,0.4$, and $0.2 \%$ respectively. $\mathrm{E}_{1} \mathrm{~S}$ standards were diluted with assay buffer supplemented with $5 \%$ plasma from nonpregnant cows. Fifteen microliters of $\mathrm{E}_{1} \mathrm{~S}$ standard (0.06$1000 \mathrm{ng} / \mathrm{ml}$ ) or plasma samples were added to each well coated with anti-rabbit $\gamma$-globulin antiserum. In addition, $100 \mu \mathrm{l}$ anti- $\mathrm{E}_{1} \mathrm{~S}(\times 2000000)$ were distributed into all wells and then incubated for $16 \mathrm{~h}$ at $4{ }^{\circ} \mathrm{C}$. After decanting the plates, $100 \mu \mathrm{l} \mathrm{E}_{1} \mathrm{~S}-\mathrm{HRP}(\times 800000)$ was distributed into all wells and then incubated for $2 \mathrm{~h}$ at $4{ }^{\circ} \mathrm{C}$. Finally, colorimetric treatment was carried out. The ED50 value of the assay was $32.0 \mathrm{ng} / \mathrm{ml}$. Intra- and inter-assay CVs were 10.7 and $15.2 \%$ respectively.

\section{Reverse transcription and real-time PCR}

Total RNA was individually isolated from COT and CAR using ISOGEN (NipponGene, Toyama, Japan) and reverse transcribed using QuantiTect Reverse Transcription Kit (Qiagen Inc.) according to the manufacturer's instructions.

Real-time PCR was performed (run in duplicate) using QuantiTect SYBR Green PCR Kit (Qiagen) and Chromo 4 Realtime PCR system (Bio-Rad Laboratories, Inc). The primers for SULT1E1, STS, CYP19, and ACTB and annealing temperatures are listed in Table 2. The thermal cycling conditions included the activation step of HotStarTaq DNA polymerase at $95{ }^{\circ} \mathrm{C}$ for $15 \mathrm{~min}$, followed by 45 cycles of denaturation at $94{ }^{\circ} \mathrm{C}$ for $15 \mathrm{~s}$; annealing of primers at different temperatures (Table 2) for $30 \mathrm{~s}$; and elongation at $72{ }^{\circ} \mathrm{C}$ for $30 \mathrm{~s}$. To quantify the mRNA abundances, standard curves for each gene were generated by serial dilution of a known quantity of purified RT-PCR products. The relative difference in the initial amount of each mRNA species was determined by comparing the $C_{\mathrm{t}}$ values. We confirmed the melting curve for detecting the SYBR Greenbased objective amplicon because SYBR Green also detects double-stranded DNA, including primer dimers, contaminating DNA and PCR products from misannealed primers. The expression ratio of each gene to ACTB mRNA was calculated for adjustment of the amount of RNA used the RT-PCR.
Correlation analyses between mRNA abundances in placental tissues (COT and CAR) and maternal plasma estrogen $\left(E_{1}, E_{1} S\right.$, and $\left.E_{2}\right)$ concentrations at parturition were performed using the data obtained from clone pregnancies.

\section{In situ hybridization}

Digoxigenin (DIG)-labeled anti-sense and sense cRNA for SULT1E1 and STS were prepared using DIG RNA Labeling Kit (Roche Diagnostics $\mathrm{GmbH}$ ) including T7 RNA polymerase. T3 RNA polymerase (Roche) was purchased separately. Briefly, RT-PCR was performed using a HotStarTaq Master Mix Kit (Qiagen) and specific primers used for the above-mentioned real-time PCR, but forward and reverse primers were added from the T3 and T7 promoter sequence to the $5^{\prime}$-end respectively. A total of $200 \mathrm{ng}$ PCR products were used as templates for synthesizing a hybridization probe. Paraffin-embedded placentomes were sectioned into $7 \mu \mathrm{m}$ thick sections. In situ hybridization was performed using an automated Ventana HX System Discovery with a RiboMapKit, an AmpMapKit (Tyramide Signal Amplification system), and a BlueMapKit (BCIP/NBT stain system; Ventana, Tucson, AZ, USA). The sections were hybridized with DIG-labeled probes in Ribohybe (Ventana) hybridization solution at various temperatures $\left(61-65^{\circ} \mathrm{C}\right)$ for $6 \mathrm{~h}$, then washed for $3 \times 6 \mathrm{~min}$ in RiboWash (Ventana) at $65^{\circ} \mathrm{C}$, and fixed in RiboFix (Ventana) at $37^{\circ} \mathrm{C}$ for $10 \mathrm{~min}$. SULT1E1 and STS hybridization signals were detected using a rabbit polyclonal anti-digoxigenin HRP conjugate (Dako Cytomation, Carpinteria, CA, USA; Table 2).

\section{Immunohistochemistry}

Paraffin-embedded placentomes were sectioned into $7 \mu \mathrm{m}$ thick sections. Immunohistochemistry was performed using an automated Ventana HX System Discovery with a DAB Map kit (Ventana). Briefly, the sections were incubated with an antiaromatase polyclonal antibody (\#3599-100, Biovision Research Products, Mountain View, CA, USA) diluted 1:20 in Discovery Ab diluent (Ventana) for $30 \mathrm{~min}$ at room temperature. Signals were detected using an anti-rabbit IgG polyclonal antibody biotin conjugate (Sigma).

\section{Number of BNC}

Five micrometer sections of paraffin-embedded placentomes were prepared and stained with hematoxylin-eosin. Three

Table 2 Oligonucleotide primers used for real-time RT-PCR analysis.

\begin{tabular}{|c|c|c|c|c|}
\hline Gene & Primer & Sequence & Annealing $\left({ }^{\circ} \mathrm{C}\right)$ & Reference \\
\hline SULT1E1 & Forward & $5^{\prime}$ CCTGAGTGGGGATTGAAGAA $3^{\prime}$ & 58 & - \\
\hline (M54942) & Reverse & 5' CACAGGCAGGTGAGACTTCA 3' & & \\
\hline STS & Forward & $5^{\prime}$ CGTCAAAGGGGAAGTTCAAG $3^{\prime}$ & 61 & - \\
\hline$(\mathrm{AB} 331885)$ & Reverse & 5’ AGATGTCCATGTTGCTGGTG 3' & & \\
\hline CYP19 & Forward & 5' AAATTACTTCСССТGAGATCAA $3^{\prime}$ & 57 & Furbass et al. (1997) \\
\hline (NM_174305) & Reverse & 5’ GACTCTCATGAATTCTCCATACATCT 3' & & \\
\hline$A C T \bar{B}$ & Forward & 5' AACTGGGACGACATGGAGAAGATCTGGCA 3' & 61 & Parent et al. (2002) \\
\hline (NM_173979) & Reverse & 5' GAGGATCTTCATGAAGGTAGTCTGTCAGGTC 3' & & \\
\hline
\end{tabular}


fields $\left(0.109 \mathrm{~mm}^{2} /\right.$ field $)$ of view of each placentome section were recorded under the light microscope with a digital photo system. Basal secondary villi or tertiary villi (Schuler et al. 2006) were examined for evaluation of BNC. Average number of $\mathrm{BNC}$ in three fields was calculated as a representative value and corrected to per $0.1 \mathrm{~mm}^{2}$.

\section{Statistical analysis}

All results are presented as the mean \pm s.E.M. Statistical analysis was performed using the Kruskal-Wallis test and Scheffe's test for post hoc analysis except that results of real-time PCR were analyzed using two-way ANOVA and Scheffe's test. Significance of the correlation coefficient between hormonal concentrations and mRNA abundances was assessed by regression analysis.

\section{Declaration of interest}

The authors declare that there is no conflict of interest that could be perceived as prejudicing the impartiality of the research reported.

\section{Funding}

This study was supported by a Grant-in-Aid for Young Scientists (B) No. 18780213 from the Ministry of Education, Culture, Sports, Science and Technology of Japan.

\section{References}

Acosta TJ, Miyamoto A, Ozawa T, Wijayagunawardane MPB \& Sato K 1998 Local release of steroid hormones, prostaglandin $E_{2}$, and endothelin-1 from bovine mature follicles in vitro: effects of luteinizing hormone, endothelin-1, and cytokines. Biology of Reproduction 59 437-443.

Acosta TJ, Yoshizawa N, Ohtani M \& Miyamoto A 2002 Local changes in blood flow within the early and midcycle corpus luteum after prostaglandin $F_{2 \alpha}$ injection in the cow. Biology of Reproduction 66 651-658.

Arnold DR, Bordignon V, Lefebvre R, Murphy BD \& Smith LC 2006 Somatic cell nuclear transfer alters peri-implantation trophoblast differentiation in bovine embryos. Reproduction 132 279-290.

Breeveld-Dwarkasing VNA, Struijk PC, Lotgering FK, Eijskoot F, Kindahl H, van der Weijden GC \& Taverne MAM 2003 Cervical dilatation related to uterine electromyographic activity and endocrinological changes during prostaglandin $\mathrm{F}_{2 \alpha}$-induced parturition in cows. Biology of Reproduction $68536-542$.

Brown JM, Adams JB \& Beattie CW 1987 Production and characterization of a monoclonal antibody to bovine estrogen sulfotransferase. Hybridoma 6 413-422.

Campbell KHS, Fisher P, Chen WC, Choi I, Kelly RDW, Lee JH \& Xhu J 2007 Somatic cell nuclear transfer: past, present and future perspectives. Theriogenology 68S S214-S231.

Chavatte-Palmer $P$, Heyman $Y$, Richard C, Monget $P$, LeBourhis D, Kann G, Chilliard Y, Vignon X \& Renard JP 2002 Clinical, hormonal, and hematologic characteristics of bovine calves derived from nuclei from somatic cells. Biology of Reproduction 66 1596-1603.

Constant F, Guillomot M, Heyman Y, Vignon X, Laigre P, Servely JL, Renard JP \& Chavatte-Palmer P 2006 Large offspring or large placenta syndrome? Morphometric analysis of late gestation bovine placentomes from somatic nuclear transfer pregnancies complicated by hydrallantois Biology of Reproduction 75 122-130.

Echternkamp SE 1993 Relationship between placental development and calf birth weight in beef cattle. Animal Reproduction Science 32 1-13.
Falany JL \& Falany CN 1996 Regulation of estrogen sulfotransferase in human endometrial adenocarcinoma cells by progesterone. Endocrinology 137 1395-1401.

Furbass R, Kalbe C \& Vanselow J 1997 Tissue-specific expression of the bovine aromatase-encoding gene uses multiple transcriptional start sites and alternative first exons. Endocrinology 138 2813-2819.

Greven H, Kowalewski MP, Hoffmann B, Geyer J, Rex-Haffner M, Ugele B \& Schuler G 2007 Bovine placental steroid sulphatase: molecular cloning and expression pattern in placentomes during gestation and at parturition. Placenta 28 889-897.

Hashizume K, Ishiwata H, Kizaki K, Yamada O, Takahashi T, Imai K, Patel OV, Akagi S, Shimizu M, Takahashi S et al. 2002 Implantation and placental development in somatic cell clone recipient cows. Cloning and Stem Cells 4 197-209.

Heyman Y, Chavatte-Palmer P, LeBourhis D, Camous S, Vignon X \& Renard JP 2002 Frequency and occurrence of late-gestation losses from cattle cloned embryos. Biology of Reproduction 66 6-13.

Hill JR, Roussel AJ, Cibelli JB, Edwards JF, Hooper NL, Miller MW, Thompson JA, Looney CR, Westhusin ME, Robl JM et al. 1999 Clinical and pathologic features of cloned transgenic calves and fetuses (13 case studies). Theriogenology 51 1451-1465.

Hill JR, Edwards JF, Sawyer N, Blackwell C \& Cibelli JB 2001 Placental anomalies in a viable cloned calf. Cloning 3 83-88.

Hoffert KA, Batchelder CA, Bertolini M, Moyer AL, Famula TR, Anderson DL \& Anderson GB 2005 Measures of maternal-fetal interaction in day-30 bovine pregnancies derived from nuclear transfer. Cloning and Stem Cells 7 289-305.

Hoffmann B, Falter K, Vielemeier A, Failing K \& Schuler G 2001 Investigations on the activity of bovine placental oestrogen sulfotransferase and -sulfatase from midgestation to parturition. Experimental and Clinical Endocrinology and Diabetes 109 294-301.

Isobe N \& Nakao T 2002 Direct enzyme immunoassay of estrone sulfate in the plasma of cattle. Journal of Reproduction and Development 48 75-78.

Lee RSF, Peterson AJ, Donnison MJ, Ravelich S, Ledgard AM, Li N, Oliver JE, Miller AL, Tucker FC, Breier B et al. 2004 Cloned cattle fetuses with the same nuclear genetics are more variable than contemporary half-siblings resulting from artificial insemination and exhibit fetal and placental growth deregulation even in the first trimester. Biology of Reproduction 70 1-11.

Matsuzaki M \& Shiga K 2002 Endocrine characteristics of cloned calves. Cloning and Stem Cells 4 261-267.

Miyamoto A, Okuda K, Schweigert FJ \& Schams D 1992 Effects of basic fibroblast growth factor, transforming growth factor-beta and nerve growth factor on the secretory function of the bovine corpus luteum in vitro. Journal of Endocrinology 135 103-114.

Pace MM, Augenstein ML, Betthauser JM, Childs LA, Eilertsen KJ, Enos JM, Forsberg EJ, Golueke PJ, Graber DF, Kemper JC et al. 2002 Ontogeny of cloned cattle to lactation. Biology of Reproduction 67 334-339.

Parent J, Chapdelaine P, Sirois J \& Fortier MA 2002 Expression of microsomal prostaglandin $\mathrm{E}$ synthase in bovine endometrium: coexpression with cyclooxygenase type 2 and regulation by interferon-tau. Endocrinology 143 2936-2943.

Patel OV, Takenouchi N, Takahashi T, Hirako M, Sasaki N \& Domeki I 1999 Plasma oestrone and oestradiol concentrations throughout gestation in cattle: relationship to stage of gestation and fetal number. Research in Veterinary Science 66 129-133.

Qian YM \& Song WC 1999 Regulation of estrogen sulfotransferase expression in leydig cells by cyclic adenosine $3^{\prime}, 5^{\prime}$-monophosphate and androgen. Endocrinology 140 1048-1053.

Ravelich SR, Breier BH, Reddy S, Keelan JA, Wells DN, Peterson AJ \& Lee RSF 2004 Insulin-like growth factor-l and binding proteins 1, 2, and 3 in bovine nuclear transfer pregnancies. Biology of Reproduction 70 430-438.

Rossier G \& Pierrepoint CG 1974 Oestrogen metabolism in sheep myometrium. Journal of Reproduction and Fertility 37 43-49.

Sawai K, Kageyama S, Moriyasu S, Hirayama H, Minamihashi A \& Onoe S 2005 Analysis of mRNA transcripts for insulin-like growth factor receptors and binding proteins in bovine embryos derived from somatic cell nuclear transfer. Cloning and Stem Cells 7 189-198.

Schuler G, Ozalp GR, Hoffmann B, Harada N, Browne P \& Conley AJ 2006 Reciprocal expression of $17 \alpha$-hydroxylase-C17,20-lyase and aromatase cytochrome P450 during bovine trophoblast differentiation: a two-cell system drives placental oestrogen synthesis. Reproduction 131 669-679. 
Takahashi T, Hirako M, Takahashi H, Patel OV, Takenouchi N \& Domeki I 1997 Maternal plasma estrone sulfate profile during pregnancy in the cow; comparison between singleton and twin pregnancies. Journal of Veterinary Medical Science 59 287-288.

Takenouchi N, Oshima K, Shimada K \& Takahashi M 2004 The development of a sensitive enzyme immunoassay for the determination of estrone and estradiol-17 $\beta$ in bovine blood plasma based on the same homologous combination with antiserum and steroid-enzyme conjugate. Journal of Veterinary Medical Science 66 1315-1321.

Tsumagari S, Kamata J, Takagi K, Tanemura K, Yosai A \& Takeishi M 1993 Aromatase activity and oestrogen concentrations in bovine cotyledons and caruncles during gestation and parturition. Journal of Reproduction and Fertility 98 631-636.

Wathes DC \& Porter DG 1982 Effect of uterine distension and oestrogen treatment on gap junction formation in the myometrium of the rat. Journal of Reproduction and Fertility 65 497-505.
Wood CE 1999 Control of parturition in ruminants. Journal of Reproduction and Fertility 54 115-126.

Young LE, Sinclair KD \& Wilmut I 1998 Large offspring syndrome in cattle and sheep. Reviews of Reproduction 3 155-163.

Zhang WC, Nakao T, Moriyoshi M, Nakada K, Ohtaki T, Ribadu AY \& Tanaka Y 1999 The relationship between plasma oestrone sulphate concentrations in pregnant dairy cattle and calf birth weight, calf viability, placental weight and placental expulsion. Animal Reproduction Science $\mathbf{5 4} 169-178$

Received 8 April 2008

First decision 14 May 2008

Revised manuscript received 15 July 2008

Accepted 28 July 2008 